\title{
Potential Germination Success of Exotic and Native Trees Coexisting in Central Spain Riparian Forests
}

\author{
Isabel Cabra-Rivas and Pilar Castro-Díez \\ Departamento de Ciencias de la Vida, Unidad Docente de Ecología, Facultad de Ciencias, Universidad de Alcalá, N-II, \\ Km 33.6, P.O. Box 20, Alcalá de Henares, 28805 Madrid, Spain
}

Correspondence should be addressed to Isabel Cabra-Rivas; isabel.cabra@uah.es

Received 18 October 2015; Accepted 15 March 2016

Academic Editor: L. M. Chu

Copyright (C) 2016 I. Cabra-Rivas and P. Castro-Díez. This is an open access article distributed under the Creative Commons Attribution License, which permits unrestricted use, distribution, and reproduction in any medium, provided the original work is properly cited.

\begin{abstract}
We compared potential germination success (i.e., percentage of produced seeds that germinate under optimal conditions), the percentage of empty and insect-damaged seeds, germinability $\left(G_{\max }\right)$, and time to germination $\left(T_{\text {germ }}\right)$ between the exotics Ailanthus altissima, Robinia pseudoacacia, and Ulmus pumila and two coexisting native trees (Fraxinus angustifolia and Ulmus minor) in the riparian forests of Central Spain. Additionally, we tested the effect of seed age, seed bank type (canopy or soil) and population on $G_{\max }$ and $T_{\text {germ }}$ of A. altissima and R. pseudoacacia, which are seed-banking species. Species ranked by their potential germination success were A. altissima $>U$. pumila $>$ R. pseudoacacia $>U$. minor $>$ F. angustifolia. The combination of a high $G_{\max }$ and negligible seed insect-damage provided $A$. altissima with a potential germination advantage over the natives, which were the least successful due to an extremely high percentage of empty seeds or a very low $G_{\max } \cdot R$. pseudoacacia showed high vulnerability to insect seed predation which might be compensated with the maintenance of persistent seed banks with high $G_{\max }$. $G_{\max }$ and $T_{\text {germ }}$ were strongly affected by seed age in the seed-banking invaders, but between-seed bank variation of $G_{\max }$ and $T_{\text {germ }}$ did not show a consistent pattern across species and populations.
\end{abstract}

\section{Introduction}

Determining what plant traits are associated with invasiveness of alien species has been a major question in invasion biology during the last decades $[1,2]$. Biological invasions involve the arrival of species to regions where they have not previously occurred, followed by rapid multiplication and range expansion [3]. The quantity and quality of available propagules influence dispersal and spread in the novel environments [4]. Vegetative reproduction may promote a rapid local dominance, but reproduction by seeds is a crucial step for invasive plants to attain an efficient range expansion and establishment far beyond their introduction point [57]. According to Hulme and Benkman [8], seeds not only contribute to the colonization of new areas but also allow the replacement of individuals ensuring population persistence after unfavourable periods.

From seed formation until seed germination, a variety of factors are responsible for the decrease in the potential number of new plants to be recruited. Among these factors, we can mention genetic/developmental effects, dispersal distance, seed viability, seed predation, and germinability. These factors act sequentially or in conjunction, sometimes leading to severe reproductive losses, and therefore compromise plant recruitment $[8,9]$. Subsequently, only a small fraction of the seed set ends up as established seedlings. A variable proportion of seeds produced by a plant may be nonviable, either due to fruit abortion $[10,11]$ or due to predation during ripening $[12,13]$. In some species, Crawley [14] quantified losses by predispersal seed predation which represented nearly $50 \%$ of the total seed crop. Besides, not all seeds escaping predation are able to successfully germinate. Germination is a vulnerable stage in the plant cycle [15]. It is a complex phenomenon controlled by genetic and environmental factors, such as light, temperature, moisture, and nutrient availability, which vary during the year [16-20]. Some species form banks of dormant seeds, which may germinate throughout subsequent years. Seed banks are stored genotypes produced in different 
years that act as reservoirs of genetic variation [21] and affect community dynamics [22]. They allow the species to recruit in years of low seed production [23], thus spreading the chances of reproduction through time [24] and expanding the window for recruitment [25]. These facts make them particularly relevant in areas where the environmental heterogeneity in space and time is high, such as Mediterranean ecosystems [26]. Seeds from seed banks may be stored in soils (soil seed bank) or/and in plant canopies (canopy seed banks). The latter have been mostly interpreted as an adaptation to fire (seeds remain in sealed cavities of fruits until they are burned, i.e., serotiny) [27]. However, some species retaining canopy seed banks are not characteristic of fire-prone ecosystems. In this context, the extent to which germination success of invasive plants is affected by seed bank type (canopy versus soil) and seed age in seed-banking species has been largely ignored.

Floodplains are among the most vulnerable habitats for plant invasions in Mediterranean regions [28]. In Mediterranean riparian forests of central Spain, there are invasive seed-banking (i.e., Ailanthus altissima (Mill.) Swingle, Robinia pseudoacacia L.) and non-seed-banking tree species (i.e., Ulmus pumila L.) successfully coexisting with native species (i.e., Fraxinus angustifolia L. and Ulmus minor (Mill.)). Our intentions with this study are (1) to compare several variables accounting for potential germination success (seed viability, predispersal seed predation, germinability, and time to germination of viable seeds) among the abovementioned coexisting invasive and native trees and (2) to examine the role of seed bank type, seed age, and provenance on the potential germination success of the seed-banking invasive trees. We hypothesize that species with greater invasive success (i.e., A. altissima and R. pseudoacacia [2931]) will show higher potential germination success when compared with natives. Besides, on the basis of the "enemy release hypothesis" [32-34], we expect seed predation to be greater in the native than in the invasive species. Finally, we expect germinability and time to germination to be dependent upon seed bank type (canopy/soil bank) and seed age.

\section{Materials and Methods}

2.1. Study Site. Native floodplain forests in Central Spain have undergone a historic process of degradation, due to agriculture, farming, river regulation, and so forth. Riparian forests of the Henares River are dominated by Populus spp., Salix spp., Ulmus minor, and Fraxinus angustifolia [35]. However, during the last decades, these areas have been colonized by exotic species, which are able to displace natural vegetation [36]. Two study sites, Jadraque (Guadalajara Province, $40^{\circ} 56^{\prime} \mathrm{N}, 2^{\circ} 56^{\prime} \mathrm{W} ; 808$ m.a.s.l.) and Alcalá (Madrid Province, $40^{\circ} 29^{\prime} \mathrm{N}, 3^{\circ} 19^{\prime} \mathrm{W} ; 600 \mathrm{~m}$.a.s.l.), were selected $70 \mathrm{~km}$ apart along the riparian forests of the Henares River (Central Spain) (Figure 1). In Jadraque, A. altissima (Mill.) Swingle and $R$. pseudoacacia L. are the prevailing exotic trees, forming dense stands among a natural matrix of Populus alba L. and F. angustifolia (Vahl). In Alcalá, remnant patches of $U$. minor (Mill.) coexist with the exotic Siberian elm (U. pumila L.),

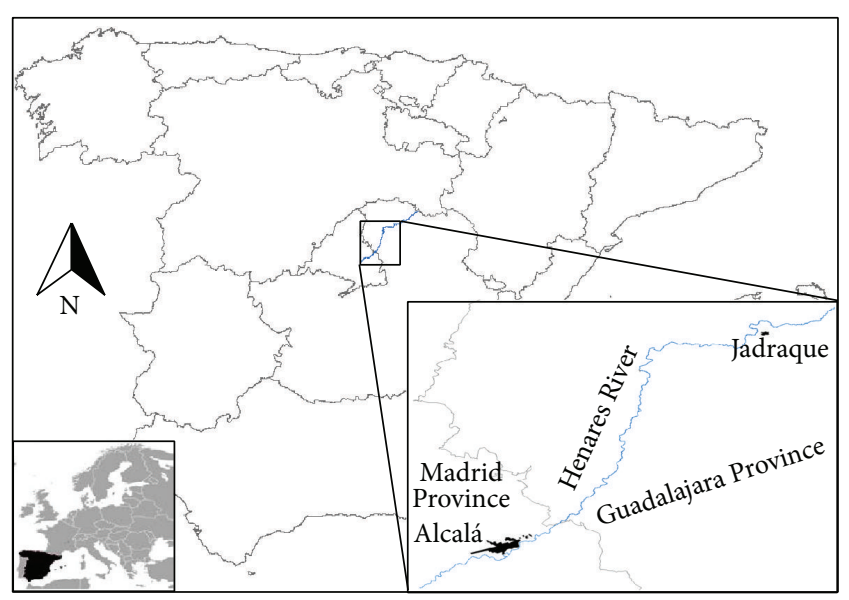

FIGURE 1: Map of the study sites (Jadraque and Alcalá) along the floodplain of the Henares River, Central Spain.

which is widely spread in this area. Here, naturalized stands of A. altissima and R. pseudoacacia are also common [37]. The climate is continental Mediterranean, with cold winters and hot and arid summers. Mean annual temperature and precipitation in each location are $10.9^{\circ} \mathrm{C} / 601 \mathrm{~mm}$ and $13.4^{\circ} \mathrm{C} / 401 \mathrm{~mm}$ (weather stations of Sigüenza and Alcalá de Henares; observation periods, 1933-1970 and 1931-1966, resp.) (Figure 1).

2.2. Study Species. The natives U. minor and F. angustifolia are wind-dispersed species that complete fruit set in March-April and September-October, respectively [38]. These species cooccur in our study sites with naturalized exotic trees such as A. altissima (wind-dispersed), R. pseudoacacia (barochorous), and U. pumila (wind-dispersed). A. altissima (native to SE Asia) and R. pseudoacacia (native to North America) are considered global invaders [31] and included in the list of the 20 most harmful alien invasive species in Spain [29]. Both were introduced during the 18th century in Spain for ornamental purposes. Nowadays, they occupy disturbed areas as well as natural and seminatural habitats, such as riparian forests, where they can displace native vegetation $[36,39]$. These species are prolific seed producers [40, 41], complete fruit ripening in summer-autumn, and are able to form both canopy and soil seed banks [19, 42, 43]. Together with $A$. altissima and $R$. pseudoacacia, there is a non-seedbanking exotic tree (Ulmus pumila), native to relatively moist regions of East Asia. U. pumila was probably introduced in the 16th century in Spain and has spread throughout the Iberian Peninsula [44]. Although it is not considered as invasive by the current Spanish legislation [45], it has shown a great potential to form dense stands in the wild and to spread, both in Spain and in other countries (United States, Canada, Mexico, and Argentina) [46-48]. This species reproduces normally by seeds, which ripen in spring and disperse by wind in a few weeks, rapidly germinating $[49,50]$.

Seed viability in $R$. pseudoacacia has been reported to be shorter than a winter [19] or to extend up to four decades [51]. In the case of A. altissima, Kota et al. [43] and Hildebrand 
TABLE 1: Summary of multispecies comparison germination tests indicating the native and exotic species tested within each location and the presence/absence of applied pretreatment.

\begin{tabular}{|c|c|c|c|}
\hline Germination test & Location & Species (status) & Pretreatment \\
\hline \multirow{4}{*}{ March 2013} & \multirow{4}{*}{ Jadraque } & A. altissima $(\mathrm{E})$ & - \\
\hline & & R. pseudoacacia (E) & - \\
\hline & & R. pseudoacacia (E) & Scarification \\
\hline & & F. angustifolia $(\mathrm{N})$ & - \\
\hline \multirow{5}{*}{ April 2013} & \multirow{5}{*}{ Alcalá } & A. altissima (E) & - \\
\hline & & R. pseudoacacia (E) & - \\
\hline & & R. pseudoacacia (E) & Scarification \\
\hline & & U. pumila (E) & - \\
\hline & & $U . \operatorname{minor}(\mathrm{N})$ & - \\
\hline
\end{tabular}

(E) exotic; (N) native.

[52] reported seed longevity of less than one year, while others reported seeds to be viable after three years of storage [20].

2.3. Experimental Design. In March 2013, we collected ripe fruits from the canopy of two exotics (R. pseudoacacia and $A$. altissima) and the native $F$. angustifolia coexisting in Jadraque. In April 2013 we collected ripe fruits from the three exotics (U. pumila, R. pseudoacacia, and A. altissima) and the native $U$. minor coexisting in Alcalá. Although seeds from the former three species ripen in autumn, they may remain in the canopy, disperse all year round, but germinate mostly in spring (personal observation). For each site and species, we pooled together harvested seeds from 10 fruiting trees. A subsample of 100 seeds per species and site was used to test seed viability. Each seed was dissected and classified as (1) empty (with malformed or no embryo), (2) insect-predated (with holes or larva inside), and (3) viable (with intact and healthy embryo).

Germination tests were performed comparing exotic and native species within each site (Table 1). Holed seeds or suspicions of containing larvae inside were discarded. Winged seeds were devoid of their wings and $R$. pseudoacacia seeds were released from their pods. Seeds were sprayed with fungicide (DITIVER; $3 \mathrm{mg} / \mathrm{L}$ ), placed over three layers of filter paper (FILTER-LAB; $0.17 \mathrm{~mm}$ width), and moistened with $5 \mathrm{~mL}$ of distilled water in $90 \mathrm{~mm}$ Petri dishes. Filter papers were kept soaked throughout the experiment. 15 Petri dishes (10 seeds/dish) per species and site were used as replicates and placed in a germination chamber (AL658 AQUALYTIC) at $20.5 \pm 0.2^{\circ} \mathrm{C}$ and $12: 12 \mathrm{~h}$ photoperiod $\left(496.2 \pm 81.5 \mu \mathrm{mol} / \mathrm{m}^{2} / \mathrm{s}\right)$, as these conditions mimic those of the study area in spring and are optimal for germination [53]. Temperature, relative humidity, and photosynthetic photon flux density (PPFD) were recorded every hour throughout the experiment with climatic sensors connected to data loggers (HOBO model H08-006-04; Onset, Pocasset, MA, USA).

Given that $R$. pseudoacacia seeds present dormancy [19], we used two sets of seeds for germination tests, one untreated and the other pretreated, to break dormancy. Based on previous experiments and studies [54], the best pretreatment consisted of scarifying them with boiling water $\left(90^{\circ} \mathrm{C}\right)$ for one minute, subsequently removing them from heat and keeping them in water for $24 \mathrm{~h}$. We did not pretreat F. angustifolia seeds because at the time of collection they had already overwintered in the crowns, and therefore they had naturally undergone cold stratification, which is considered to break dormancy in this species [55]. Petri dishes were randomly distributed in the germination chamber and rotated every 3 4 days to avoid position effects. The number of germinated seeds was recorded daily until no more germinated seeds were observed for, at least, 9 consecutive days. Protrusion of the radicle or any part of the embryo was used as germination criterion. Germinated seeds were removed from the dishes at each census. Once the germination test was concluded, nongerminated seeds were dissected to exclude nonviable ones (i.e., empty or with larvae inside) from the counting. For each replicate we assessed the cumulative germination of viable seeds at the end of the experiment $\left(G_{\max }\right.$ in \%) and the average time required by seeds to germinate $\left(T_{\text {germ }}\right.$ in days). Finally, we assessed the potential germination success $\left(G_{\text {succ }}\right.$ in \%) by multiplying $G_{\max }$ by the percentage of viable seeds, representing the proportion of produced seeds that are able to germinate under favourable conditions $\left(G_{\text {succ }}=\right.$ $G_{\max } \times \%$ viable seeds).

In late September 2011, ripe fruits of $A$. altissima and $R$. pseudoacacia were collected from 10 adult trees belonging to the same two populations as before (Jadraque and Alcalá). For each species and site, a subset of 150 healthy seeds was used for a germination test (canopy seed bank, see below) and the remaining seeds were used to simulate a soil seed bank as follows: for each species and population, 32-33 stainless metal mesh bags $(4 \times 4 \mathrm{~cm} ; 2 \mathrm{~mm}$-mesh), containing 12 seeds each, were sealed with staples and placed outdoors on the ground at the Botanical Garden of Alcalá University (Madrid Province, $40^{\circ} 30^{\prime} \mathrm{N}, 3^{\circ} 20^{\prime} \mathrm{W}$, altitude 596 m.a.s.1.). They were covered with a layer of $A$. altissima and $R$. pseudoacacia leaf litter collected in the sampling sites and protected from the local fauna with a $4.5 \mathrm{~mm}$ openings plastic mesh, fixed with nails to the ground. From November 2011 to October 2012, we performed one germination test every three months, in the same conditions as described in the previous section, using 150 healthy seeds recently collected from the tree crowns (canopy seed bank) and 150 healthy seeds from the simulated soil seed bank, per species and population (15 replicates of 10 seeds per species, population, and seed bank). In the November 2011 test, only canopy seed bank was used as the soil seed bank was not available yet. For each replicate, we calculated $G_{\max }$ and $T_{\text {germ }}$ as before.

2.4. Data Analysis. Given that data did not meet normality, we conducted generalized linear models (GLMs) to compare $G_{\text {max }}, T_{\text {germ }}$, and proportions of empty, insect-damaged, and viable seeds across species. As not all species were present at the two sites (Jadraque/Alcalá), analyses were performed separately for each population. Besides, given that $R$. pseudoacacia values of germination were obtained for both untreated and pretreated seeds, analyses were conducted twice, using one set of data in each case. We chose binomial error distribution and logit link function for proportions 
TABLE 2: Seed mean dry weight, cumulative seed germination $\left(G_{\max }\right)$, mean time to germination $\left(T_{\text {germ }}\right)$, and germination success $\left(G_{\text {succ }}=\right.$ $G_{\max } * \%$ viable seeds) of the studied species in the 2013 experiment (means \pm SE). In R. pseudoacacia, values in parentheses correspond to untreated seeds. In the case of A. altissima and R. pseudoacacia values for different populations (Jadraque and Alcalá) are shown.

\begin{tabular}{|c|c|c|c|c|c|c|c|c|}
\hline Site & Species & Dry weight (mg) & Viable seeds & Empty seeds & $\begin{array}{l}\text { Insect- } \\
\text { damaged } \\
\text { seeds }\end{array}$ & $G_{\max }(\%)$ & $T_{\text {germ }}$ (days) & $G_{\text {succ }}(\%)$ \\
\hline \multirow{3}{*}{ Jadraque } & A. altissima & $19.9 \pm 0.4$ & $100 \pm 0^{\mathrm{b}}$ & $0 \pm 0^{\mathrm{a}}$ & $0 \pm 0^{\mathrm{a}}$ & $67 \pm 4^{\mathrm{b}, \mathrm{A}}$ & $12 \pm 1^{\mathrm{b}}$ & 67 \\
\hline & R. pseudoacacia & $15.8 \pm 0.2$ & $50 \pm 6^{\mathrm{a}}$ & $35 \pm 5^{\mathrm{b}, \mathrm{A}}$ & $15 \pm 4^{\mathrm{b}}$ & $68 \pm 4^{\mathrm{b}, \mathrm{A}}(14 \pm 3)^{\mathrm{a}, \mathrm{B}, *}$ & $7 \pm 1^{\mathrm{a}, \mathrm{B}}(7 \pm 1)^{\mathrm{a}}$ & $33(6)$ \\
\hline & F. angustifolia & $48.0 \pm 1.9$ & $79 \pm 5^{\mathrm{ab}}$ & $19 \pm 5^{\mathrm{b}}$ & $2 \pm 1^{\mathrm{a}}$ & $14 \pm 4^{\mathrm{a}}$ & $14 \pm 1^{\mathrm{b}}$ & 11 \\
\hline \multirow{4}{*}{ Alcalá } & A. altissima & $24.6 \pm 0.4$ & $98 \pm 1^{c}$ & $2 \pm 1^{\mathrm{a}}$ & $0 \pm 0^{\mathrm{a}}$ & $97 \pm 2^{b, B}$ & $12 \pm 1^{c}$ & 94 \\
\hline & R. pseudoacacia & $16.6 \pm 0.3$ & $59 \pm 7^{\mathrm{ab}}$ & $12 \pm 3^{\mathrm{ab}, \mathrm{B}}$ & $29 \pm 8^{\mathrm{b}}$ & $92 \pm 2^{\mathrm{b}, \mathrm{B}}(7 \pm 2)^{\mathrm{a}, \mathrm{A}, *}$ & $3 \pm 0^{\mathrm{a}, \mathrm{A}}(6 \pm 1)^{\mathrm{b}, *}$ & $54(4)$ \\
\hline & U. pumila & $9.7 \pm 0.2$ & $73 \pm 4^{\mathrm{b}}$ & $27 \pm 4^{\mathrm{b}}$ & $0 \pm 0^{\mathrm{a}}$ & $99 \pm 1^{b}$ & $2 \pm 0^{\mathrm{a}}$ & 73 \\
\hline & U. minor & $5.1 \pm 0.2$ & $36 \pm 5^{\mathrm{a}}$ & $64 \pm 5^{c}$ & $0 \pm 0^{\mathrm{a}}$ & $91 \pm 3^{\mathrm{b}}$ & $2 \pm 0^{\mathrm{a}}$ & 33 \\
\hline
\end{tabular}

Lowercase letters indicate significant interspecific differences within each site on the basis of multiple comparison post hoc test. For species present in both sites (A. altissima and R. pseudoacacia), uppercase letters indicate significant differences between populations (Wilcoxon test). ${ }^{*}$ Significant differences between pretreated and nontreated R. pseudoacacia seeds in the same parameter, on the basis of a Wilcoxon test.

(percentages of empty, insect-damaged, and viable seeds and $\left.G_{\max }\right)$ and Poisson error and log link function for counts $\left(T_{\text {germ }}\right)$. Whenever significant differences among species were found, post hoc Tukey's all-pairwise comparisons were conducted in $\mathrm{R}$ with the glht function in the software package multcomp [56].

Additionally, for species present in both sites (i.e., $R$. pseudoacacia and A. altissima), Wilcoxon test was performed to compare percentages of empty, insect-damaged, and viable seeds and $G_{\max }$ and $T_{\text {germ }}$ between populations. Similarly, we tested the effect of $R$. pseudoacacia pretreatment on $G_{\max }$ and $T_{\text {germ }}$ with a Wilcoxon test, comparing untreated and pretreated seeds belonging to the same population.

The effect of (i) seed age, (ii) seed bank type, and (iii) population on $G_{\max }$ (binomial response) and $T_{\text {germ }}$ (Poisson response) was tested separately for the species A. altissima and R. pseudoacacia using GLMs. Seed age, seed bank type, and population were used as fixed factors, and the interaction between seed bank type and population was included. The most parsimonious models were retained. All the analyses were performed with R 3.0.1 statistical package [57].

\section{Results}

Seed viability differed largely among species, the ranking being $A$. altissima $\geq F$. angustifolia $\geq R$. pseudoacacia in Jadraque and A. altissima $>U$. pumila $\geq R$. pseudoacacia $\geq$ $U$. minor in Alcalá (Table 2). This fact was the consequence of the proportion of empty seeds, except for R. pseudoacacia of Alcalá, whose low proportion of viable seeds was due to a relatively high proportion of insect-damaged seeds. The native $U$. minor exhibited a very high proportion of empty seeds $(64 \%)$. Insect-damage was irrelevant in all species except for R. pseudoacacia (Table 2). The percentage of insectdamaged and viable seeds did not differ between populations in A. altissima or in R. pseudoacacia (Table 2). The percentage of empty seeds was also similar between populations in $A$. altissima, but in $R$. pseudoacacia it was higher in Jadraque than in Alcalá $(W=90.5 ; P=0.002)($ Table 2$)$.
In Jadraque, $G_{\max }$ was similar between A. altissima and pretreated R. pseudoacacia and higher than that of F. angustifolia (Table 2). In Alcalá, $G_{\max }$ was similar across species and higher than $90 \%$ in all of them (considering pretreated seeds in R. pseudoacacia) (Table 2 and Figure S1 available online at http://dx.doi.org/10.1155/2016/7614683). $G_{\max }$ of pretreated $R$. pseudoacacia was superior to untreated seeds in both populations (Table $2, W=225 ; P<0.001$ ). $G_{\max }$ widely varied between populations of the two invaders, being higher in Alcalá (Table 2). After multiplying $G_{\max }$ by the proportion of viable seeds (i.e., $G_{\text {succ }}$ ), A. altissima was the species with the most successful potential germination in the two sites, followed by U. pumila in Alcalá and by R. pseudoacacia in Jadraque. The two native species showed the least $G_{\text {succ }}$ in Jadraque (F. angustifolia) and in Alcalá (U. minor).

F. angustifolia and $A$. altissima were the species that required longer time to germinate $\left(T_{\text {germ }}=14\right.$ days and 12 days, resp.). $R$. pseudoacacia showed an intermediate $T_{\text {germ }}$ and the Ulmus gender was the fastest in germinating (2 days). $R$. pseudoacacia seeds from Alcalá germinated faster when pretreated, but the same was not true for Jadraque, where both pretreated and untreated seeds took the same time to germinate (Table 2, Figure S1).

Although we are aware of some A. altissima trees retaining seeds in their canopies for more than a year (Figure S2), it was not the case for those from the studied populations, so we could perform germination tests on seeds from the canopy bank neither in August 2012 (Jadraque) nor in October 2012 (Jadraque and Alcalá). Nevertheless, seeds from the soil bank retained high viability after one year (>65\%) (Figure 2 ). Seeds of $R$. pseudoacacia remained in the canopy during the whole monitored year (Figure 2).

Seed age and population were the factors that contributed the most to explaining the variation of $G_{\max }$ in both species (Table 3). In A. altissima, $G_{\max }$ increased rapidly until May (94.4\%) and then slowly declined until October (72.2\%) (Figure 2). In $R$. pseudoacacia, $G_{\max }$ ranged from $32.3 \%$ to $93.4 \%$, peaking in August, except for the seeds of the canopy bank of Jadraque, which showed erratic dynamics (Figure 2(b), Table S1). Seeds from Alcalá showed higher $G_{\max }$ 
TABLE 3: Generalized linear models assessing the importance of seed age, seed bank type, and population on cumulative seed germination $\left(G_{\max }\right)$ and mean time to germinate $\left(T_{\mathrm{germ}}\right)$ in A. altissima and $R$. pseudoacacia in the 2011-2012 experiment.

\begin{tabular}{|c|c|c|c|c|c|c|c|c|c|c|c|c|c|c|c|c|}
\hline \multirow{3}{*}{$\begin{array}{l}\text { Species } \\
\text { Response variables }\end{array}$} & \multicolumn{8}{|c|}{ A. altissima } & \multicolumn{8}{|c|}{ R. pseudoacacia } \\
\hline & \multicolumn{4}{|c|}{$G_{\max }$} & \multicolumn{4}{|c|}{$T_{\text {germ }}$} & \multicolumn{4}{|c|}{$G_{\max }$} & \multicolumn{4}{|c|}{$T_{\text {germ }}$} \\
\hline & $\mathrm{df}$ & $\mathrm{D}$ & $\mathrm{RD}$ & $P$ & df & $\mathrm{D}$ & $\mathrm{RD}$ & $P$ & df & $\mathrm{D}$ & $\mathrm{RD}$ & $P$ & $\mathrm{df}$ & $\mathrm{D}$ & $\mathrm{RD}$ & $P$ \\
\hline \multicolumn{17}{|l|}{$\begin{array}{l}\text { Explanatory } \\
\text { variables }\end{array}$} \\
\hline Seed age (SA) & 4 & 263.913 & 330.46 & $<0.001$ & 4 & 149.826 & 249.72 & $<0.001$ & 4 & 91.864 & 790.66 & $<0.001$ & 4 & 140.983 & 469.72 & $<0.001$ \\
\hline $\begin{array}{l}\text { Seed bank type } \\
\text { (SBT) }\end{array}$ & - & - & - & NS & 1 & 70.299 & 179.42 & $<0.001$ & 1 & 4.093 & 786.57 & 0.04 & 1 & 7.932 & 461.79 & 0.005 \\
\hline $\begin{array}{l}\text { Population } \\
\text { (POP) }\end{array}$ & 1 & 23.766 & 306.70 & $<0.001$ & 1 & 2.692 & 176.73 & NS & 1 & 29.579 & 756.99 & $<0.001$ & 1 & 125.783 & 336.01 & $<0.001$ \\
\hline $\mathrm{SBT} \times \mathrm{POP}$ & - & - & - & NS & 1 & 6.767 & 169.96 & 0.01 & 1 & 4.784 & 752.21 & 0.03 & - & - & - & NS \\
\hline
\end{tabular}

(df) degrees of freedom; (D) deviance; (RD) residual deviance; $(P) P$ value of $\chi^{2}$ test used to evaluate if selected predictors explain a significant fraction of the deviance; NS, not significant).

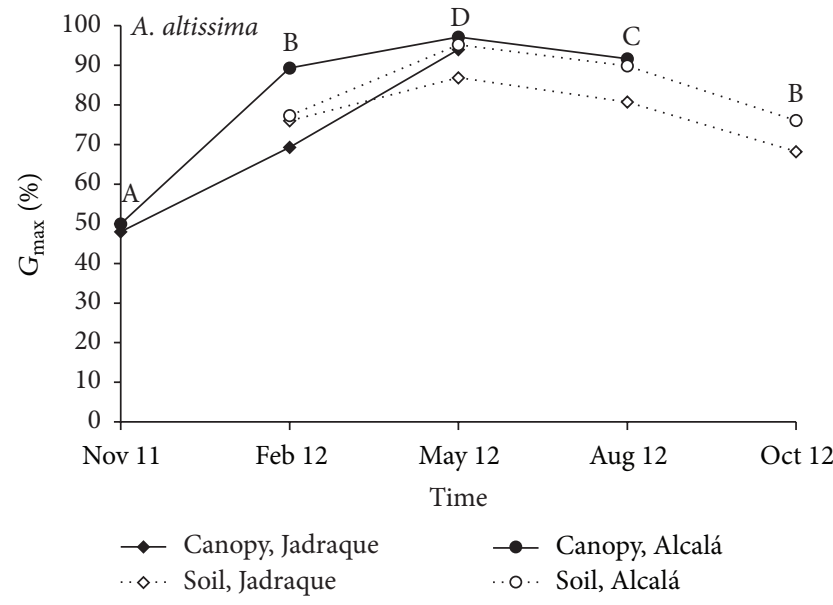

(a)

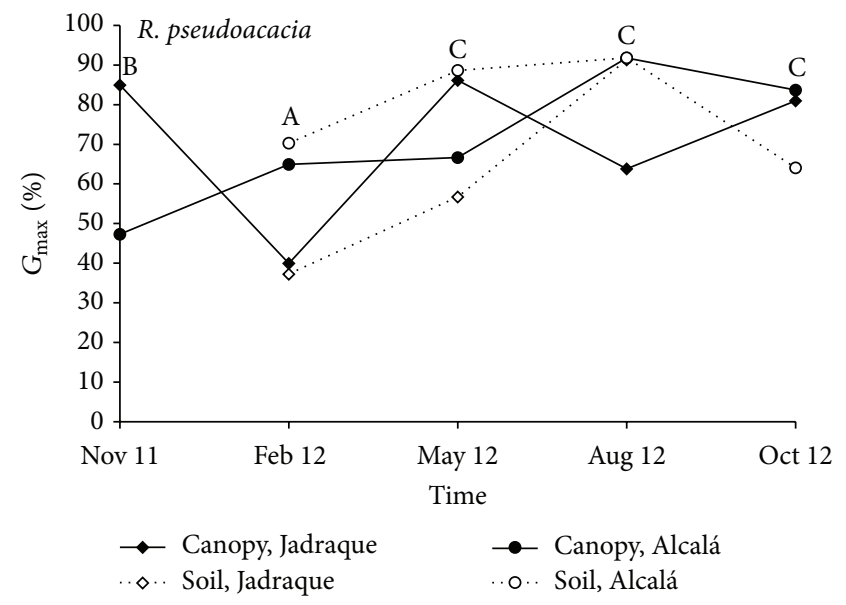

(b)

FIGURE 2: Maximum proportion of germinated seeds $\left(G_{\max }\right)$ from the canopy and soil seed banks of Ailanthus altissima and Robinia pseudoacacia from two populations (Jadraque and Alcalá) throughout a year $(N=150)$. Uppercase letters represent significant differences $(P<0.05)$ in $G_{\max }$ among seeds of different age (i.e., at different moments of the year).

in both species (Figure 2). Finally, seed bank type did not have any effect on $G_{\max }$ in A. Altissima seeds but somewhat affected $G_{\max }$ in R. pseudoacacia $(P=0.043)$ (Table 3), seeds from the soil bank showing a slightly higher $G_{\max }$ than those from the canopy.

Seed age and seed bank type played an important role in determining $T_{\text {germ }}$ both for A. altissima and R. pseudoacacia (Table 3). A. altissima seeds germinated faster (lower $T_{\text {germ }}$ ) in May (10.5 days) and October ( 9.5 days) than in the remaining months, whereas $R$. pseudoacacia showed its fastest germination in August (3 days) (Figure 3; Table S1). Seeds from the canopy bank of A. altissima emerged 6 days later than those from the soil bank (Figure 3). By contrast $R$. pseudoacacia seeds from the soil bank germinated later than those of the canopy, although this difference was only relevant in Jadraque (Table 3, Figure 3). Population was a more influential factor than seed bank type on $T_{\text {germ }}$ for R. pseudoacacia (seeds from Alcalá germinating faster than seeds from Jadraque) but it did not have an effect on $T_{\text {germ }}$ for A. Altissima (Table 3, Figure 3).

\section{Discussion}

Our results show that exotic species benefited from several characteristics that helped them increase the potential germination success over natives. It was the combination of various features that led exotics to outperform natives in terms of potential germination success. Among the studied species, A. altissima was the most successful in terms of $G_{\text {succ }}$. This species showed a low proportion of empty seeds, virtually no insect attack, and very high germinability. These properties, along with the prolific seed production [40] and the longdistance seed dispersal by wind and water [58-60], provide this species with a very high potential to quickly spread far beyond the introduction point, which is the condition of naturalized exotic plants to be considered as invasive [3]. Besides, this species also attains a high degree of dominance at local scale due to its profuse resprout [61]. Altogether, these properties help explain why A. altissima is considered as one of the top invaders, both in Spain [29] and in the world [31]. 


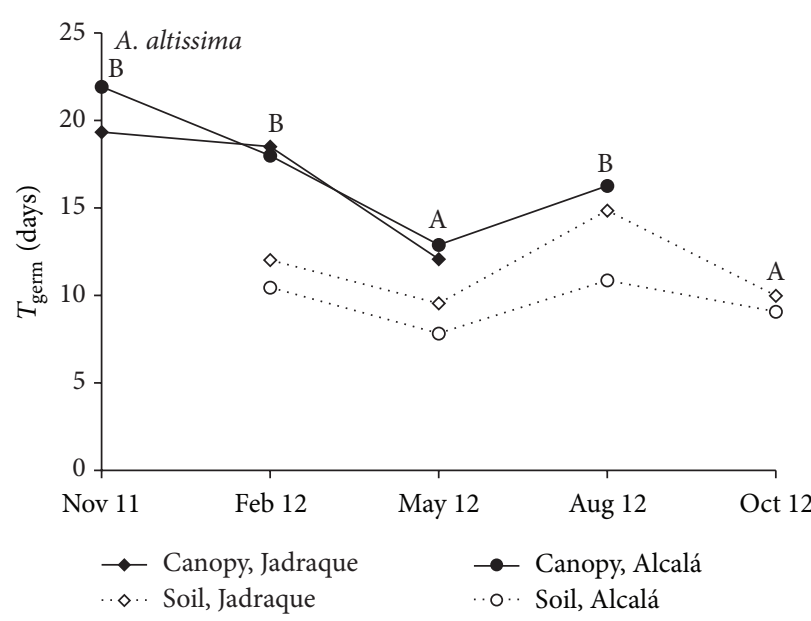

(a)

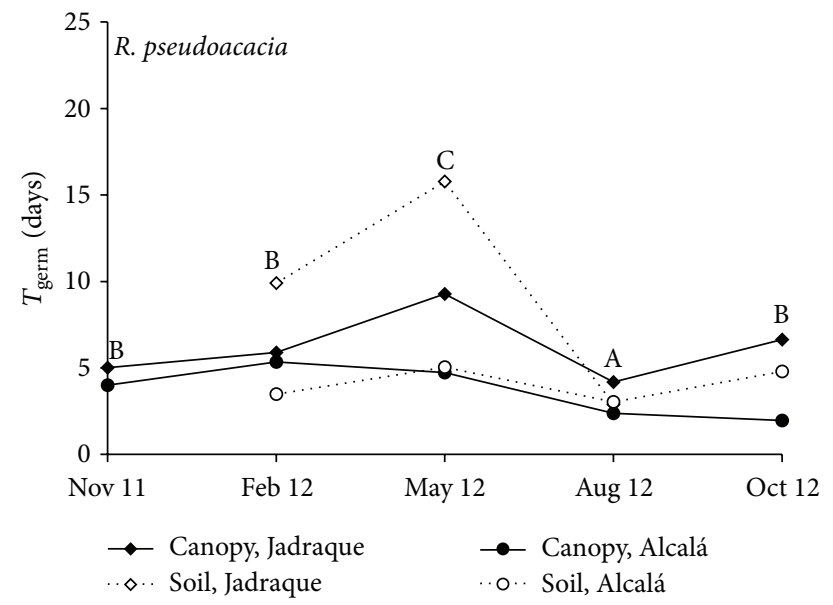

(b)

Figure 3: Time to germinate $\left(T_{\text {germ }}\right)$ of Ailanthus altissima and Robinia pseudoacacia seeds from the canopy and soil seed banks from two populations (Jadraque and Alcalá) throughout a year. Uppercase letters represent significant differences in $T_{\text {germ }}$ among seeds of different age (i.e., at different moments of the year).

Despite the fact that U. pumila is not considered an invasive species in Spain [45], we found that it had a high potential germination success (only overcome by $A$. altissima) because of its high germinability (nearly 100\%), negligible predispersal insect attack, and moderate proportion of empty seeds. In addition, U. pumila seeds may present a relatively high longevity, as Dulamsuren et al. [62] found seeds from the previous growing season retaining $92 \%$ of germinability. Like A. altissima, this species also produces large quantities of wind-dispersed seeds [63]. This makes U. pumila also a good candidate for a quick spread from the introduction point. In fact, we have observed a high recruitment of this species in abandoned fields, crop and road borders, and even riparian forests of Central Spain. Therefore, we suggest that its "noninvasive" status should be revised.

Although $R$. pseudoacacia is also considered as a top invader in several sources [29, 31], in terms of potential germination success, we find it to be far below A. altissima and even $U$. pumila. A relatively high proportion of empty and insect-damaged seeds contributed to this low success. However, unlike A. altissima and U. pumila, R. pseudoacacia seeds present dormancy, which can be broken by natural processes, such as the passage through the digestive track of animals, fires, or abrasion with soil particles [64]. Even if dormancy depresses germination success of a seed cohort in the short term, at longer time scales it may increase reproductive success by extending the temporal window for germination [22]. Furthermore, the formation of longlasting seed banks associated with seed dormancy represents a challenge to attain long-term eradication [65-67].

The two native species showed the lowest potential germination success: in the case of $U$. minor due to the high proportion of empty seeds and in the case of F. angustifolia due to its low germinability. These results match those of Gérard et al. [68] reporting germinability of 2-20\% for F. angustifolia. However, other authors have shown stratification to largely increase germinability of this species $[69,70]$. Given that our seeds underwent stratification in the wild (they overwintered in the trees), our low germination rate may be attributed to a secondary dormancy induced by constant temperatures of $20^{\circ} \mathrm{C}$ during the germination assay $[69,71,72]$. In any case, literature also indicates a relatively high proportion of empty seeds for this species [72].

Against our hypothesis 2, we did not find seed predation to cause higher seed losses in native than in invasive species. Indeed, the invasive $R$. pseudoacacia was the most affected by insect seed predation. Many seed traits may affect the choice of fruit species by animals, such as morphology, weight, size, chemical composition, or fruiting phenology [73-75]. The null predation of Ulmus seeds may be partly explained by the fact that they were collected within 3-5 weeks since fruit set, while seeds of the remaining species had been exposed to predators for a fairly long period ( 9 to 11 months since the beginning of fruit set). However, only one known insect, the larva of Cirrhia gilvago, feeds on elm samara, and it is quite infrequent in Europe [76]. In the case of A. altissima, a high content of bitter-tasting quassinoid compounds [77] may explain the negligible predation of its seeds. Accordingly, Kelbel [78] also found that A. altissima seeds were not damaged by predators in a multispecies experiment. On the other hand, the high predation of $R$. pseudoacacia seeds may be attributed to their high protein and sugar content (unpublished data), as these compounds have been positively associated with fruit infestation $[74,79,80]$. Producing empty seeds may also contribute to reduce pre- and postdispersal seed predation [81-83]. This is a common phenomenon in wind-dispersed trees, for which animals mainly act as seed predators, rather than dispersers [84]. Given that, for a seed predator, the cost of seed-handling increases as the proportion of full seeds decreases, possessing empty seeds may contribute to overall plant fitness by discouraging animals to search for full seeds [11, 84]. This argument matches with the results 
found for the anemochorous species U. pumila, U. minor, and $F$. angustifolia, which showed a relatively high proportion of empty seeds and a low proportion of seed predation. We should also note that, in the particular case of $U$. minor, the extremely high proportion of empty samaras (64\%) agrees with results reported by Laguna [85], Cogolludo-Agustín et al. [44], and López-Almansa and Gil [86] and may be due to either seed abortion [87] or inbreeding depression undergone by U. minor population caused by Dutch Elm Disease (DED) (present in Spain since the beginning of the 1930s [88]). DED induces canopy decay of large trees, which are the most prolific. Although trees may profusely resprout after infection, juvenile resprouts have scarce sexual reproduction, leading to a genetic impoverishment of populations [89].

Overall, our results show that all the three exotics species (A. altissima $>U$. pumila $>$ R. pseudoacacia) could potentially outperform natives, especially when colonizing open sites by seeds. For instance, A. altissima and $R$. pseudoacacia recruit better under high levels of irradiance, contrary to the natives $U$. minor and $F$. angustifolia which recruit better under moderate levels of irradiance [90].

Finally, as we expected, there was a clear effect of seed age on germination parameters $\left(G_{\max }\right.$ and $\left.T_{\text {germ }}\right)$. However, the influence of seed bank type varied depending on the studied species and population. Seed germinability $\left(G_{\max }\right)$ was found to be strongly dependent on seed age in both species, peaking in May-August and slightly declining until the following autumn. The fact that germinability peaked in or near the beginning of the arid summer agrees with the humid/subhumid origin of these species $[91,92]$ and suggests a lack of adaptation to the Mediterranean environment. This contributes to explaining why, in Spain, these species invade habitats where summer drought is somehow mitigated (floodplains, crop borders, road sides, etc.) [36]. Our findings also emphasize the importance of accounting for agedependent variations in germination tests when comparing species. For instance, our cross-species experiment comparing seeds collected in March-April may have underestimated the potential germination of A. altissima and R. pseudoacacia, which reach their maximum later.

Although we found $G_{\max }$ to be slightly superior in the soil seed bank of $R$. pseudoacacia, no differences were found between seed banks in $A$. altissima. $T_{\text {germ }}$ varied across seed banks in different ways for each species. Therefore, there does not seem to be a consistent superiority of one seed bank over the other. Alternatively, the advantage might be possessing both seed banks, rather than only one. Some species have tried to counterbalance environmental pressures through certain mechanisms aiming at spreading the risk of sexual reproduction failure through time [24], for example by spreading germination along the year or along several years. This prevents parental fitness from dropping in years of unfavourable conditions for germination or seedling survival [93]. Possessing two seed bank types may further contribute to spreading the risk of germination failure, for instance, by splitting the risk of predation between soil and canopy seed-eaters.

The fact that the between-seed bank variation of $G_{\max }$ and $T_{\text {germ }}$ did not show a consistent pattern across species and populations suggests that the optimal environmental conditions for a successful germination differ between seed banks. However, although significant, differences in time to emergence between seed banks are of few days; therefore, they might not be ecologically meaningful. Overall, variation across populations in germination traits may reflect genetic differences between populations or local adaptations of the species to different conditions, as reported previously for invasive populations of $R$. pseudoacacia [19] and A. altissima [20].

\section{Conclusions}

Our results suggest that the combination of certain characteristics such as high germinability and seed viability provides the exotic trees A. altissima and U. pumila with a higher potential germination success than cooccurring natives. Furthermore, the ability of $A$. altissima and $R$. pseudoacacia to maintain at least one seed bank type, viable during more than one year, brings about a large temporal window for recruitment, and more chances for a successful germination under heterogeneous conditions. Finally, seed age should be accounted for when studying germination responses (i.e., $G_{\max }$ or $\left.T_{\text {germ }}\right)$ in seed-banking species. All these factors should be considered in management strategies to eradicate or control populations of these invasive trees.

\section{Competing Interests}

The authors declare that there is no conflict of interests regarding the publication of this paper.

\section{Acknowledgments}

This study was supported by Project CGL2010-16388/BOS of the Spanish Ministry of Economy and Competitiveness, POII10-0179-4700 of the Junta de Comunidades de CastillaLa Mancha, and REMEDINAL network S2009/AMB-1783 of the Comunidad de Madrid. Isabel Cabra-Rivas was supported by a grant from the Spanish Ministry of Education, Culture and Sport (FPU Fellowship, AP2010-1513) and by a grant from Alcalá University. The authors acknowledge Rosendo Elvira and the staff of the Alcalá University Botanical Garden for their support to perform this experiment. The authors also thank Guillermo Valle Torres and Alejandra Blánquez Moya for their valuable help during field sampling and laboratory work.

\section{References}

[1] M. van Kleunen, W. Dawson, D. Schlaepfer, J. M. Jeschke, and M. Fischer, "Are invaders different? A conceptual framework of comparative approaches for assessing determinants of invasiveness," Ecology Letters, vol. 13, no. 8, pp. 947-958, 2010.

[2] R. E. Drenovsky, A. Khasanova, and J. J. James, "Trait convergence and plasticity among native and invasive species in resource-poor environments," American Journal of Botany, vol. 99, no. 4, pp. 629-639, 2012.

[3] D. M. Richardson, P. Pyšek, M. Rejmánek, M. G. Barbour, F. Dane Panetta, and C. J. West, "Naturalization and invasion of 
alien plants: concepts and definitions," Diversity and Distributions, vol. 6, no. 2, pp. 93-107, 2000.

[4] S. C. Barrett, "Why reproductive systems matter for the invasion biology of plants?" in Fifty Years of Invasion Ecology: The Legacy of Charles Elton, D. Richardson, Ed., pp. 195-210, WileyBlackell, Oxford, UK, 2011.

[5] M. J. W. Burke and J. P. Grime, "An experimental study of plant community invasibility," Ecology, vol. 77, no. 3, pp. 776-790, 1996.

[6] M. C. Muñoz and J. D. Ackerman, "Spatial distribution and performance of native and invasive Ardisia (Myrsinaceae) species in Puerto Rico: the anatomy of an invasion," Biological Invasions, vol. 13, no. 7, pp. 1543-1558, 2011.

[7] H. Hirsch, C. Wypior, H. von Wehrden, K. Wesche, D. Renison, and I. Hensen, "Germination performance of native and nonnative Ulmus pumila populations," NeoBiota, vol. 15, pp. 53-68, 2012.

[8] P. E. Hulme and C. W. Benkman, "Granivory," in Plant Animal Interactions. An Evolutionary Approach, C. M. Herrera and O. Pellmyr, Eds., pp. 132-154, Blackwell, Oxford, UK, 2002.

[9] M. Fenner and K. Thompson, The Ecology of Seeds, Cambridge University Press, Cambridge, UK, 2005.

[10] G. Korbecka, P. G. L. Klinkhamer, and K. Vrieling, "Selective embryo abortion hypothesis revisited-a molecular approach," Plant Biology, vol. 4, no. 3, pp. 298-310, 2002.

[11] J. Ghazoul and A. Satake, "Nonviable seed set enhances plant fitness: the sacrificial sibling hypothesis," Ecology, vol. 90, no. 2, pp. 369-377, 2009.

[12] D. H. Janzen, "Seed predation by animals," Annual Review of Ecology and Systematics, vol. 2, no. 1, pp. 465-492, 1971.

[13] A. N. Andersen, "How important is seed predation to recruitment in stable populations of long-lived perennials?” Oecologia, vol. 81, no. 3, pp. 310-315, 1989.

[14] M. J. Crawley, "Seed predators and plant population dynamics," in Seeds: The Ecology of Regeneration in Plant Communities, M. Fenner, Ed., pp. 157-191, CAB International, Wallingford, UK, 1992.

[15] V. Vibekke, I. Heuch, and V. Vandvik, "Do seed mass and family affect germination and juvenile performance in Knautia arvensis? A study using failure-time methods," Acta Oecologica, vol. 25, no. 3, pp. 169-178, 2004.

[16] J. D. Bewley and M. Black, Seeds: Physiology of Development and Germination, Plenum Press, New York, NY, USA, 1985.

[17] C. C. Baskin and J. M. Baskin, Seeds: Ecology, Biogeography, and Evolution of Dormancy and Germination, Academic Press, San Diego, Calif, USA, 1998.

[18] M. Verdú and A. Traveset, "Early emergence enhances plant fitness: a phylogenetically controlled meta-analysis," Ecology, vol. 86, no. 6, pp. 1385-1394, 2005.

[19] K. Masaka and K. Yamada, "Variation in germination character of Robinia pseudoacacia L. (Leguminosae) seeds at individual tree level," Journal of Forest Research, vol. 14, no. 3, pp. 167-177, 2009.

[20] S. Constán-Nava and A. Bonet, "Genetic variability modulates the effect of habitat type and environmental conditions on early invasion success of Ailanthus altissima in Mediterranean ecosystems," Biological Invasions, vol. 14, no. 11, pp. 2379-2392, 2012.

[21] L. G. Barrett, T. He, B. B. Lamont, and S. L. Krauss, “Temporal patterns of genetic variation across a 9-year-old aerial seed bank of the shrub Banksia hookeriana (Proteaceae)," Molecular Ecology, vol. 14, no. 13, pp. 4169-4179, 2005.
[22] J. H. R. Lambers, J. S. Clark, and M. Lavine, "Implications of seed banking for recruitment of southern Appalachian woody species," Ecology, vol. 86, no. 1, pp. 85-95, 2005.

[23] M. E. Barnes, "Seed predation, germination and seedling establishment of Acacia erioloba in northern Botswana," Journal of Arid Environments, vol. 49, no. 3, pp. 541-554, 2001.

[24] T. Philippi and J. Seger, "Hedging one's evolutionary bets, revisited," Trends in Ecology and Evolution, vol. 4, no. 2, pp. 4144, 1989.

[25] M. K. J. Ooi, "Seed bank persistence and climate change," Seed Science Research, vol. 22, supplement 1, pp. S53-S60, 2012.

[26] R. Braza and M. B. García, "Spreading recruitment over time to cope with environmental variability," Plant Ecology, vol. 212, no. 2, pp. 283-292, 2011.

[27] B. B. Lamont, S. W. Connell, and S. M. Bergl, "Seed bank and population dynamics of Banksia cuneata: the role of time, fire and moisture," Botanical Gazette, vol. 152, no. 1, pp. 114-122, 1991.

[28] M. Chytrý, L. C. Maskell, J. Pino et al., "Habitat invasions by alien plants: a quantitative comparison among Mediterranean, subcontinental and oceanic regions of Europe," Journal of Applied Ecology, vol. 45, no. 2, pp. 448-458, 2008.

[29] Grupo Especialista en Invasiones Biológicas (GEIB), “TOP 20: las 20 especies exóticas invasoras más dañinas presentes en España," GEIB Serie Técnica 2, Ministerio de Medio Ambiente y Medio Rural y Marino, Madrid, Spain, 2006.

[30] DAISIE, Delivering Alien Invasive Species Inventories for Europe, Invasive Alien Species Fact Sheets, European Invasive Alien Species Gateway, 2012, http://www.europe-aliens.org.

[31] Global Invasive Species Database (GISD), January 2013, http://physicsweb.org/articles/news/11/6/16/1.

[32] C. S. Elton, The Ecology of Invasions by Animals and Plants, Chapman \& Hall, London, UK, 1958.

[33] M. A. Nuñez, D. Simberloff, and M. A. Relva, "Seed predation as a barrier to alien conifer invasions," Biological Invasions, vol. 10, no. 8, pp. 1389-1398, 2008.

[34] E. Castells, M. Morante, J. M. Blanco-Moreno, F. X. Sans, R. Vilatersana, and A. Blasco-Moreno, "Reduced seed predation after invasion supports enemy release in a broad biogeographical survey," Oecologia, vol. 173, no. 4, pp. 1397-1409, 2013.

[35] E. Blanco, M. Casado, M. Costa, R. Escribano, and M. García, Los Bosques Ibéricos: Una Interpretación Geobotánica, Planeta, Barcelona, Spain, 2005.

[36] M. Sanz-Elorza, E. Dana, and E. Sobrino, Atlas de las Plantas Alóctonas Invasoras en España, Dirección General para la Biodiversidad (Ministerio de Medio Ambiente), Madrid, Spain, 2004.

[37] I. Cabra-Rivas, P. Castro-Díez, and A. Saldaña, "Analysis of the riparian habitat invasion by three tree exotic species in Spain," Ecosistemas, vol. 24, no. 1, pp. 18-28, 2014.

[38] M. A. Prada and D. Arizpe, Riparian Tree and Shrub Propagation Handbook: An Aid to Riverine Restoration in the Mediterranean Region, Generalitat Valenciana, Valencia, Spain, 2008.

[39] S. Constán-Nava, A. Bonet, and L. Serra, "Efectos de la especie invasora Ailanthus altissima (Mill.) Swingle sobre la diversidad vegetal en bosques de ribera del LIC Serra de Mariola y Carrascal de la Font Roja," Iberis, vol. 6, pp. 65-75, 2008.

[40] G. Bory and D. Clair-Maczulajtys, "Production, dissémination et polymorphisme des semences d'Ailanthus altissima (Mill.) Swingle, Simaroubaceae," Revue Génerale de Botanique, vol. 88, pp. 297-311, 1980. 
[41] C. K. Converse, Element Stewardship Abstract for Robinia pseudoacacia, The Nature Conservancy, Arlington, Va, USA, 1984.

[42] L. Thompson, "The functional ecology of seed banks," in The Ecology of the Regeneration of Plant Communities, M. Fenner, Ed., pp. 231-258, CAB International, Wallingford, UK, 1992.

[43] N. L. Kota, R. E. Landenberger, and J. B. McGraw, "Germination and early growth of Ailanthus and tulip poplar in three levels of forest disturbance," Biological Invasions, vol. 9, no. 2, pp. 197-211, 2007.

[44] M. Á. Cogolludo-Agustín, D. Agúndez, and L. Gil, "Identification of native and hybrid elms in Spain using isozyme gene markers," Heredity, vol. 85, no. 2, pp. 157-166, 2000.

[45] MAGRAMA, Real Decreto 630/2013, de 2 de Agosto, por el que se Regula el Catálogo Español de Especies Exóticas Invasoras, BOEA-2013-8565, Ministerio de Agricultura, Alimentación y Medio Ambiente, 2013.

[46] C. A. Todzia and J. L. Panero, "A new species of Ulmus (Ulmaceae) from southern Mexico and a synopsis of the species in Mexico," Brittonia, vol. 50, no. 3, pp. 343-347, 1998.

[47] J. E. Zalapa, J. Brunet, and R. P. Guries, "Patterns of hybridization and introgression between invasive Ulmus pumila (Ulmaceae) and native U. Rubra," American Journal of Botany, vol. 96, no. 6, pp. 1116-1128, 2009.

[48] L. Brouillet, F. Coursol, S. J. Meades et al., VASCAN, The Database of Vascular Plants of Canada, 2014, http://data.canadehttp://data.canadensys.net/vascan/.

[49] M. Chang Geng, "A provenance test of white elm (Ulmus pumila L.) in China," Silvae Genetica, vol. 38, pp. 37-44, 1989.

[50] U.S. Department of Agriculture. Natural Resources Conservation Service (USDA), Field Guide for Managing Siberian Elm in the Southwest, Forest Service, Washington, DC, USA, 2012.

[51] E. H. Toole and E. Brown, "Final results of the Duvel buried seed experiment," Journal of Agricultural Research, vol. 72, pp. 201-210, 1946.

[52] N. Hildebrand, Temperature and substrate effects on the juvenile establishment of the species Ailanthus altissima (Mill.) Swingle and Acer negundo L. [M.S. thesis], University of Greenwich, Greenwich, UK, 2006.

[53] R. Serrada, Apuntes de Repoblaciones Forestales, FUCOVASA, Madrid, Spain, 2000.

[54] M. Basbag, A. Aydin, and D. Ayzit, "The effect of different temperatures and durations on the dormancy breaking of black locust (Robinia pseudoacacia L.) and honey locust (Gleditsia triacanthos L.) seeds," Notulae Scientia Biologicae, vol. 2, no. 4, pp. 125-128, 2010.

[55] F. Tilki and E. Çiçek, "Effects of stratification, temperature and storage on germination in three provenances of Fraxinus angustifolia subsp. oxycarpa seeds," Turkish Journal of Agriculture and Forestry, vol. 29, no. 4, pp. 323-330, 2005.

[56] T. Hothorn, F. Bretz, and P. Westfall, "Simultaneous inference in general parametric models," Biometrical Journal, vol. 50, no. 3 , pp. 346-363, 2008.

[57] R Core Team, R: A Language and Environment for Statistical Computing, R Foundation for Statistical Computing, Vienna, Austria, 2013, http://www.R-project.org/.

[58] M. A. Kaproth and J. B. McGraw, "Seed viability and dispersal of the wind-dispersed invasive Ailanthus altissima in aqueous environments," Forest Science, vol. 54, no. 5, pp. 490-496, 2008.

[59] I. Kowarik and M. von der Lippe, "Secondary wind dispersal enhances long-distance dispersal of an invasive species in urban road corridors," NeoBiota, vol. 9, pp. 49-70, 2011.
[60] I. Säumel and I. Kowarik, "Propagule morphology and river characteristics shape secondary water dispersal in tree species," Plant Ecology, vol. 214, no. 10, pp. 1257-1272, 2013.

[61] I. Kowarik and I. Säumel, "Biological flora of Central Europe: Ailanthus altissima (Mill.) Swingle," Perspectives in Plant Ecology, Evolution and Systematics, vol. 8, no. 4, pp. 207-237, 2007.

[62] C. Dulamsuren, M. Hauck, S. Nyambayar, D. Osokhjargal, and C. Leuschner, "Establishment of Ulmus pumila seedlings on steppe slopes of the northern Mongolian mountain taiga," Acta Oecologica, vol. 35, no. 5, pp. 563-572, 2009.

[63] Y. Tang, D.-M. Jiang, and X.-T. Lü, "Effects of exclosure management on Elm (Ulmus pumila) recruitment in Horqin Sandy Land, Northeastern China," Arid Land Research and Management, vol. 28, no. 1, pp. 109-117, 2014.

[64] J. van Staden, K. M. Kelly, and W. E. Bell, "The role of natural agents in the removal of coat-imposed dormancy in Dichrostachys cinerea (L.) Wight et Arn. seeds," Plant Growth Regulation, vol. 14, no. 1, pp. 51-59, 1994.

[65] D. M. Richardson and R. L. Kluge, "Seed banks of invasive Australian Acacia species in South Africa: role in invasiveness and options for management," Perspectives in Plant Ecology, Evolution and Systematics, vol. 10, no. 3, pp. 161-177, 2008.

[66] J. L. Fisher, W. A. Loneragan, K. Dixon, and E. J. Veneklaas, "Soil seed bank compositional change constrains biodiversity in an invaded species-rich woodland," Biological Conservation, vol. 142, no. 2, pp. 256-269, 2009.

[67] M. Gaertner, D. M. Richardson, and S. D. J. Privett, "Effects of alien plants on ecosystem structure and functioning and implications for restoration: insights from three degraded sites in South African fynbos," Environmental Management, vol. 48, no. 1, pp. 57-69, 2011.

[68] P. R. Gérard, J. F. Fernández-Manjarrés, P. Bertolino, J. Dufour, C. Raquin, and N. Frascaria-Lacoste, "New insights in the recognition of the European ash species Fraxinus excelsior L. and Fraxinus angustifolia Vahl as useful tools for forest management," Annals of Forest Science, vol. 63, no. 7, pp. 733738, 2006.

[69] B. Piotto, G. Bartolini, F. Bussotti et al., "Fact sheets on the propagation of Mediterranean trees and shrubs from seed," in Seed Propagation of Mediterranean Trees and Shrubs, B. Piotto and A. Di Noi, Eds., pp. 11-51, APAT, Rome, Italy, 2003.

[70] C. Draghici and I. V. Abrudan, "The effect of different stratification conditions on the germination of Fraxinus angustifolia Vahl. and F. ornus L. seeds," Notulae Botanicae Horti Agrobotanici Cluj-Napoca, vol. 39, no. 1, pp. 283-287, 2011.

[71] G. Catalán-Bachiller, Semillas de Árboles y Arbustos Forestales, ICONA (Ministerio de Agricultura, Pesca y Alimentación), Madrid, Spain, 1991.

[72] P. García-Fayos, J. Gulias, J. Martínez et al., Bases Ecológicas para la Recolección, Almacenamiento y Germinación de Semillas de Especies de Uso Forestal de la Comunidad Valenciana, Banc de Llavors Forestals (Consellería de Medi Ambient, Generalitat Valenciana), Valencia, Spain, 2001.

[73] F. J. R. Slansky, "Insect nutritional ecology as a basis for studying host plant resistance," The Florida Entomologist, vol. 73, no. 3, pp. 359-378, 1990.

[74] M. A. Aziz, M. ul Hasan, A. Ali, A. Suhail, and T. Sahi, "Role of different physico-chemical characters of okra as a host plant preference of Earias spp," Pakistan Journal of Zoology, vol. 42, pp. 361-369, 2012. 
[75] A. Gautier-Hion, "Seasonal variations of diet related to species and sex in a community of Cercopithecus monkeys," The Journal of Animal Ecology, vol. 49, no. 1, pp. 237-269, 1980.

[76] R. H. Richens, Elm, Cambridge University Press, Cambridge, UK, 1983.

[77] R. M. Heisey, "Identification of an allelopathic compound from Ailanthus altissima (Simaroubaceae) and characterization of its herbicidal activity," American Journal of Botany, vol. 83, no. 2, pp. 192-200, 1996.

[78] P. Kelbel, "Monitoring of carpophages of invasive and expansive wood species," Journal of Forest Science, vol. 46, no. 10, pp. 485489, 2000.

[79] R. Singh, "Effect of okra fruit blocks, seeds and pericarp on pest embryonic development of Earias vitella (Fab.) in relation to some phytochemicals of selected okra genotypes," Proceedings: Animal Sciences, vol. 96, pp. 361-367, 1987.

[80] R. Sundararaj and B. V. David, "Influence of biochemical parameters of different hosts on the biology of Earias vittella (Fab.) (Noctuidae: Lepidoptera)," Proceedings: Animal Sciences, vol. 96, no. 3, pp. 329-332, 1987.

[81] M. Fuentes and E. W. Schupp, "Empty seeds reduce seed predation by birds in Juniperus osteosperma," Evolutionary Ecology, vol. 12, no. 7, pp. 823-827, 1998.

[82] M. Verdú and P. García-Fayos, "The effect of deceptive fruits on predispersal seed predation by birds in Pistacia lentiscus," Plant Ecology, vol. 156, no. 2, pp. 245-248, 2001.

[83] M. F. Ramos-Ordoñez and M. C. Arizmendi, "Parthenocarpy, attractiveness and seed predation by birds in Bursera morelensis," Journal of Arid Environments, vol. 75, no. 9, pp. 757-762, 2011.

[84] R. Perea, M. Venturas, and L. Gil, "Empty seeds are not always bad: simultaneous effect of seed emptiness and masting on animal seed predation," PLoS ONE, vol. 8, no. 6, Article ID e65573, 2013.

[85] M. Laguna, Flora Forestal Española, Ministerio de Fomento, Madrid, Spain, 1883.

[86] J. C. López-Almansa and L. Gil, "Empty samara and parthenocarpy in Ulmus minor s.l. in Spain," Silvae Genetica, vol. 52, no. 5-6, pp. 241-243, 2003.

[87] J. C. López-Almansa, E. C. Yeung, and L. Gil, "Abortive seed development in Ulmus minor (Ulmaceae)," Botanical Journal of the Linnean Society, vol. 145, no. 4, pp. 455-467, 2004.

[88] A. Solla, M. Burón, S. Iglesias, and L. Gil, "Spanish program for the conservation and breeding of elms against DED," in The Elms: Breeding, Conservation, and Disease Management, C. P. Dunn, Ed., pp. 295-303, Kluwer Academic Publishers, Dordrecht, The Netherlands, 2000.

[89] J. C. López-Almansa, "Review. Reproductive ecology of riparian elms," Investigación Agraria: Sistemas y Recursos Forestales, vol. 13, no. 1, pp. 17-27, 2004.

[90] N. González-Muñoz, P. Castro-Díez, and N. FierroBrunnenmeister, "Establishment success of coexisting native and exotic trees under an experimental gradient of irradiance and soil moisture," Environmental Management, vol. 48, no. 4, pp. 764-773, 2011.

[91] G. R. Trimble, "Summaries of some silvical characteristics of several Appalachian hardwood trees," General Technical Report NE-16, Northeastern Forest Experiment Station, USDA Forest Service, Broomall, Pa, USA, 1975.

[92] Q. C. B. Cronk and J. L. Fuller, Plant Invaders: The Threat to Natural Ecosystems, Chapman \& Hall, London, UK, 1995.
[93] A. Mathias and É. Kisdi, "Adaptive diversification of germination strategies," Proceedings of the Royal Society B: Biological Sciences, vol. 269, no. 1487, pp. 151-155, 2002. 

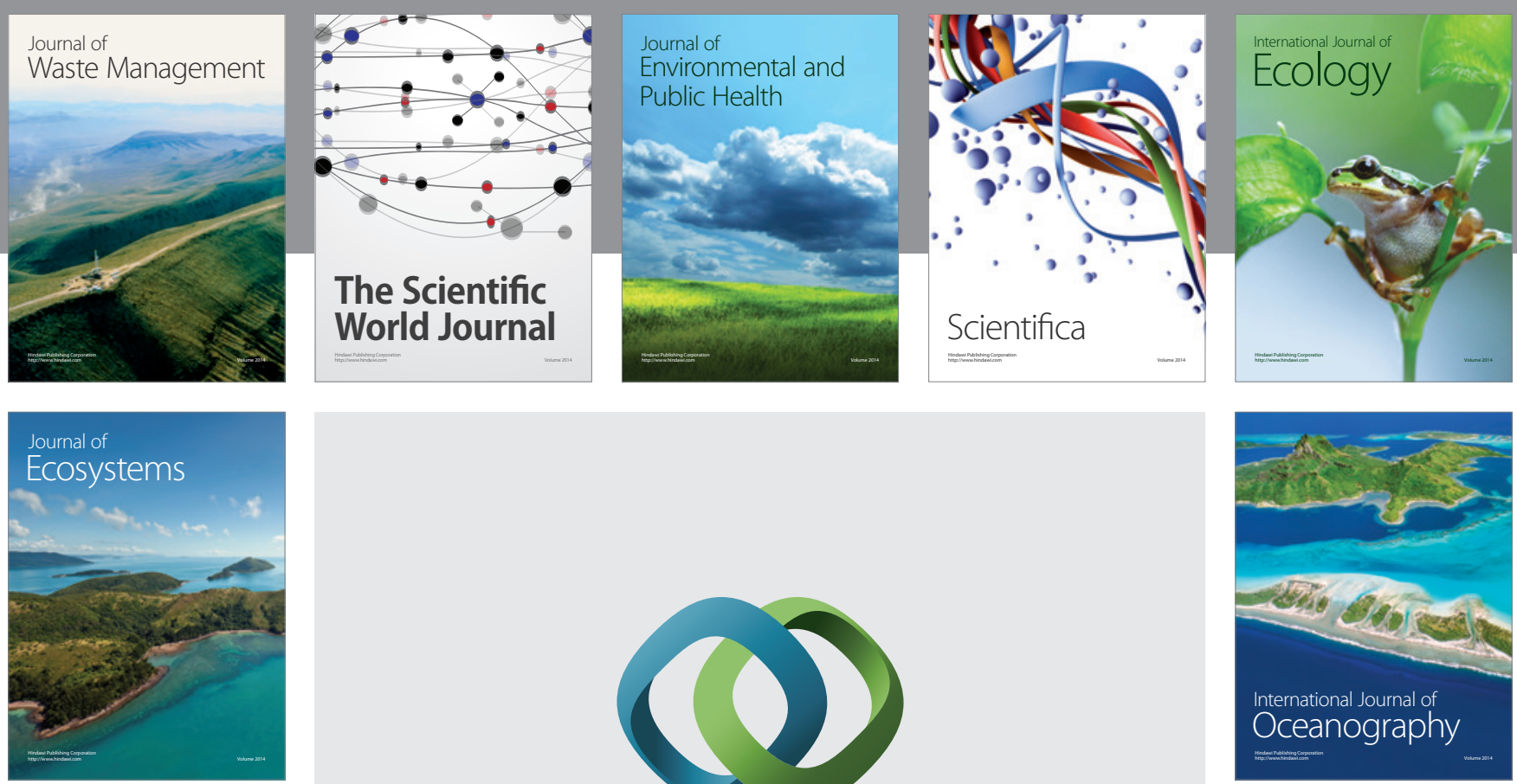

The Scientific World Journal
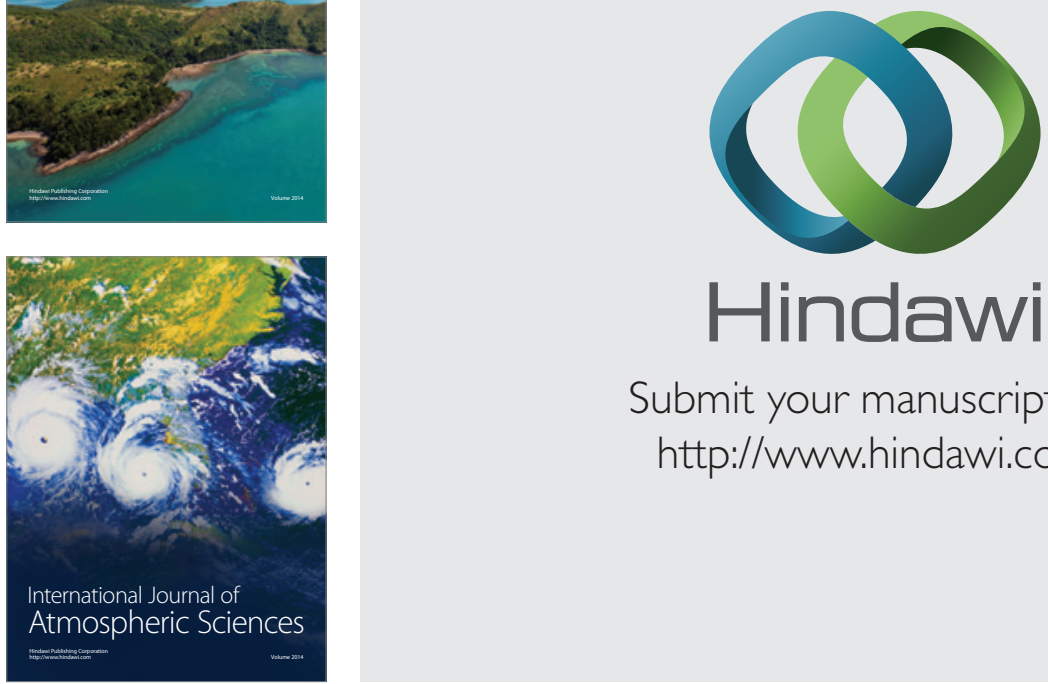

\section{Hindawi}

Submit your manuscripts at

http://www.hindawi.com
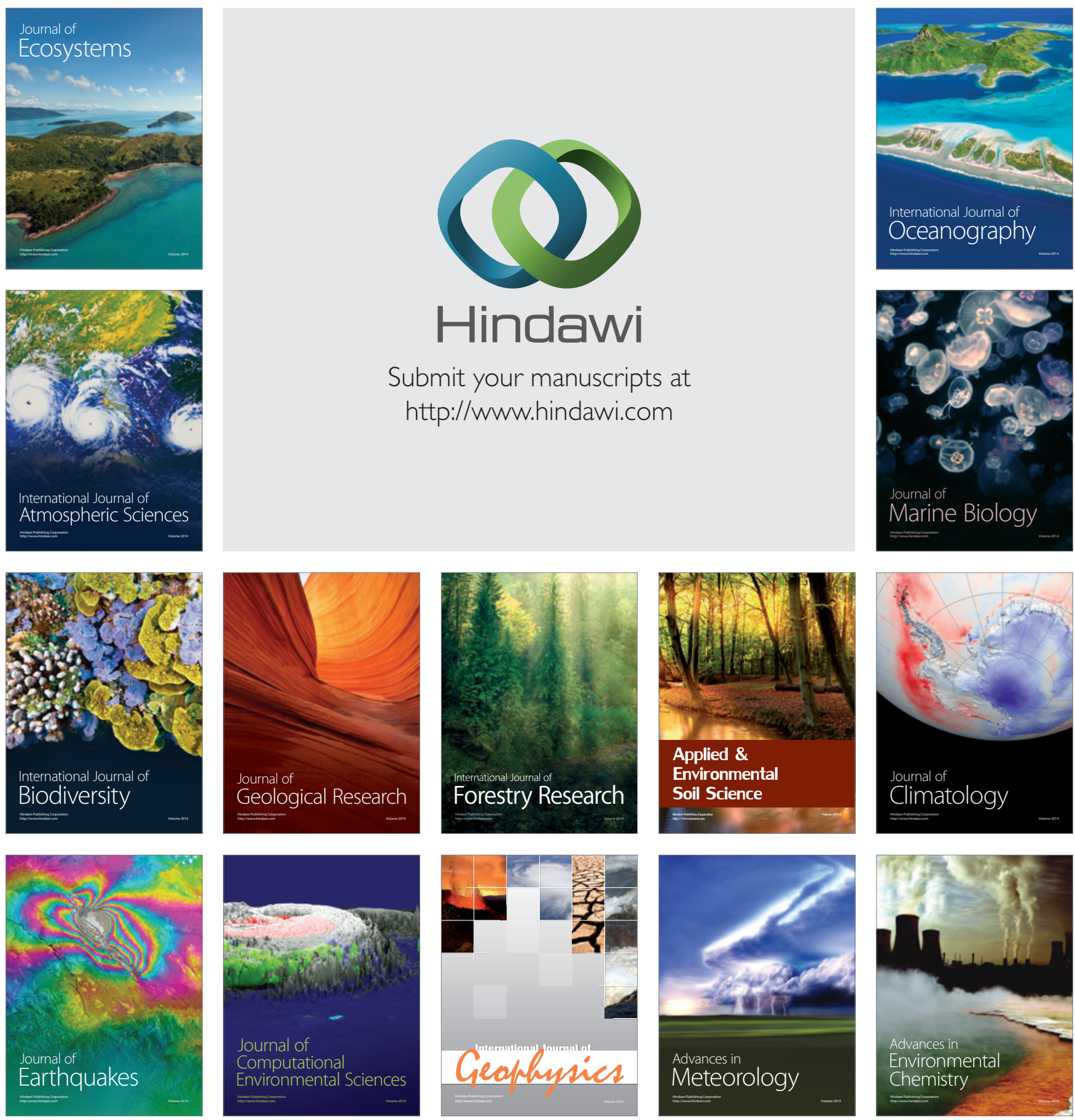